\title{
System dynamics models as decision-making tools in agritourism
}

\author{
Tadeja JERE JAKULIN \\ Univerza na Primorskem, Fakulteta za turistične študije - Turistica, Obala 11a, 6320 Portorož
}

\begin{abstract}
Agritourism as a type of niche tourism is a complex and softly defined phaenomenon. The demands for fast and integrated decision regarding agritourism and its interconnections with environment, economy (investments, traffic) and social factors (tourists) is urgent. Many different methodologies and methods master softly structured questions and dilemmas with global and local properties. Here we present methods of systems thinking and system dynamics, which were first brought into force in the educational and training area in the form of different computer simulations and later as tools for decision-making and organisational re-engineering. We develop system dynamics models in order to present accuracy of methodology. These models are essentially simple and can serve only as describers of the activity of basic mutual influences among variables. We will pay the attention to the methodology for parameter model values determination and the so-called mental model. This one is the basis of causal connections among model variables. At the end, we restore a connection between qualitative and quantitative models in frame of system dynamics.
\end{abstract}

Keywords: agritourism, multi-criteria decision-making, modelling, system dynamics

\section{INTRODUCTION}

Agritourism is a type of niche tourism and an organisational system connected to the area of clean environment, natural way of living, and healthy habitats. It is a geographic and socioeconomic, phaenomenon, which encompasses a suprasystem of tourism in general and large variety of subsystems, players and academic disciplines. It is inherently connected to the development of information technology and constant changes in the economy, environment, social, and other organisational systems. Tourism has become a major job generator (Yunis 2009).As a consequence new interconnections in and around tourism and its subsystem agritourism, are inevitable and complex. The aim of the paper is to present a systems approach to agritourism within which we develop the models for decision-making in agritourism. We claim that the systems approach represents an excellent methodology with its methods of systems modelling and simulation. Tourism systems have already tested modelling in a frame of system dynamics, which is disciplined by an organizing framework that leads to model formulation and simulation (Forrester 1994). System dynamics methodology can be used as an alternative to the econometric and mathematical programming approaches (Bockermann et al. 2005, Elshorbagy et al. 2005, Saysel et al. 2002) for agritourism modelling. The methods, which we present in order to show the accuracy of methodology, were common tools in management in the end of the last century (Senge 2010). They were first brought into force in the educational and training area in the form of different computer games and later as tools for decision-making and organisational re-engineering (Kljajićand Jere Lazanski 2005). The qualitative models, developed in the paper represent the describers of the activities and influences among defined variables.Due to the systems methodology a connection between qualitative and quantitative models is restored and a compromise between simplicity, limited usefulness and complexity is shown. The paper also present the usefulness and a critical analysis of the methodology, which is applied to a developed agritourism model. 


\section{SYSTEMS METHODOLOGY FOR DECISION-MAKING IN AGRITOURISM}

As a complex system, agritourism encompasses a wide variety of interactions among economic, environmental, social, technical, financial, and logistic elements. To avoid unnecessary costs, waste of time and unreal expectations, the decision-makers must simulate the decisions they are responsible for. The main advantage of systems methodology is the possibility of experimenting with model scenarios when limited data is available, which gives policy makers information regarding the system's potential response to different policies prior to making any decisions (Rozman et al. 2011). As we show in Fig. 1, a simulator supports the decision-makers in the decision-making process. Decision testing is an integral part of a decision-making process. With this methodology, which includes modern technology, we avoid negative intangible parts of soft systems (decisionmakers) to involve into the decision-making process. Past states determine decision-makers memory: biological, social, cultural and historical, and together with human vision they strongly influence the future state. (Kljajić and Jere Lazanski 2005)Positive intangible parts such as human skills, emotions, and creativity play an important role when the team of decision-makers tries to find solutions. To avoid information overload and complexity we use computerbased tools for group decision making. Group decisionmaking system consists of interactive software that allows for making decisions by a group of participants and improve the productivity of a group to come to a decision after different simulation scenarios analysis. The main paradigm of problem solving via simulation is shown on Fig. 1, which represents relations among participants (decision-makers), agritourism system and its simulation model.

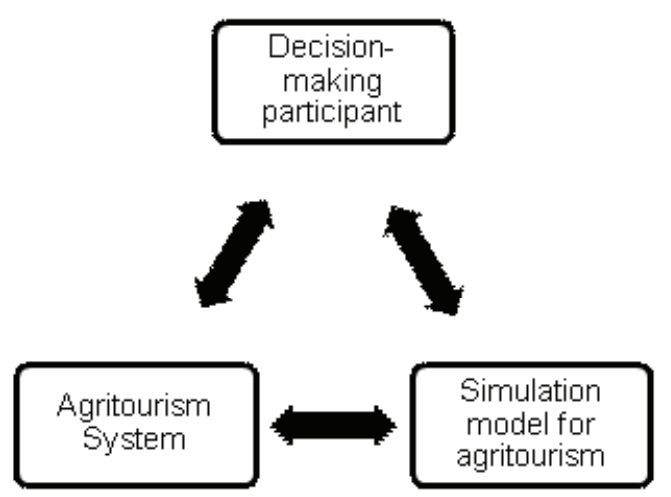

Fig.1: Simulation methodology determination with decision-makers' involvement

The concepts of state, goal, criteria, and the state of nature are connected in a dynamic model interacting with decisionmakers. The process was designed on the concept of the state-variable approach. The system for decision assessment has been organised in two hierarchical levels (Kljajić and Jere Lazanski 2005). The model at the top level is used for the assessment of agritourism development strategy. The model consists of dynamic simulation models that explicitly consider the information feedback that governs interactions within the ecosystem (Kljajić et al. 2012). At the bottom level, the model is used for discrete event simulation, necessary for operation planning and testing of production performance (Jere Lazanski 2006). The concept of state is convenient for achieving harmony among different levels throughout the whole system. In a practical sense, this means that when the discrete-event process is considered, variables are considered as entities as the level and rate in the system dynamics, when the process is considered continuous. The proposed approach supports man-machine interaction in operational planning, and the evaluation of the strategy (Kljajić 2000).

\section{CAUSAL LOOP DIAGRAM OF AGRITOURISM AREA DEVELOPMENT}

Fig. 2 represents a causal loop diagram CLD of agritourism development area model, which can be described as follows: attractive agritourism area $(+)$ influences in the same direction onto agritourism development. Agritourism development $(+)$ influences in the same direction onto quality of life and services $(+)$, which influences upon number of tourists, $(+)$, number of tourists influences growth of investments into infrastructure and agritourism development $(+)$. On the other hand, it can be said: more tourists $(+)$ cause damage to agritourism area attractiveness (-), which is a reason for falling of quality of life and services. At the same time, the increase of seasonal traffic at the roads, which lead to agritourism area, represents crowding $(+)$, which causes detours, traffic standstills, drivers' nervousness, accidents, anger and regrets for making a decision and having vacation in the area. (-)

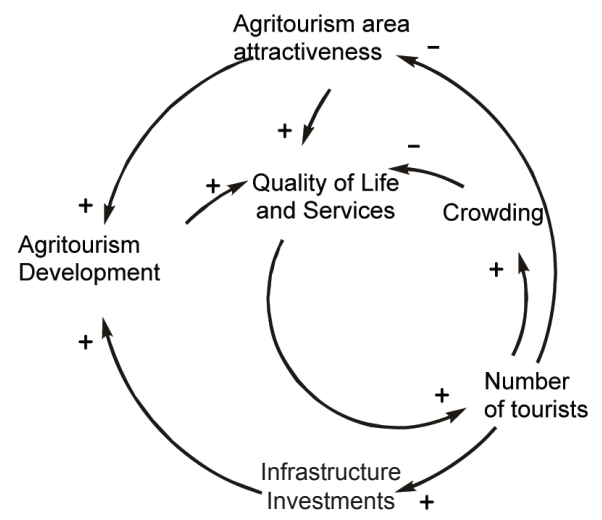

Fig. 2: CLD (causal loop diagram) as simplified influential dependency diagram of agritourism area attractiveness, number of tourists, agritourism development and investments.(Authors own figure and concepts)

From these qualitative descriptions we build an influential diagram (qualitative model) of our simplified system, shown on fig.3. From a model one can derive that there is one basic circle (-) of causal loop, which means growth of number of tourists and borders of growth, caused by infrastructure and environment damaging. In a vision of agritourism development we have to predict development as a whole in order to avoid limitations. If in the reinforcement circle, 
which consists from investments, environment preservation, only one element start to fall (-), this means fall of all other elements.

To move to a quantitative model capable of cause consequence analysis of decision makers' impacts on the longterm behaviour, the influence matrix must be transformed to SD methodology (Kljajić et al. 2012).

\section{SIMULATION MODEL FOR AGRITOURISM IN FRAME OF SYSTEM DYNAMICS}

System dynamics methodology enables using all points of view as a whole (Kljajić and Borštnar 2011)and its application towards a developmentan alternative farm tourism model would clearly be a novelty. Figure 3 represents a system dynamics model depicting the interaction among agritourism area attractiveness, number of tourists, agritourism development and investments into infrastructure.SD model follows the above developed and in fig. 2 described causal loop diagram. We can claim that the "model" is perfect in the sense that its nonlinear stock-flow-feedback structure, its parameters, its distribution of random variates, and its initial values, are identical to those of the "real world system." The "model" is thus more perfectly specified than any actual social system model could ever be in the true real world (Jere Lazanski 2006). Stocks or Levels show a variable type and a model object in SD models, used to represent the state variables of a system. Levels accumulate connected flows. Array Stock has one dimension with different elements and flows in a SDmodel represent the transport of quantities to, from, and between levels, whereas connectors are links to establish an influence from one variable to another. The environmental impacts of conducting agritourism are influential factors, (Kidd 2009) which is also seen in fig.3

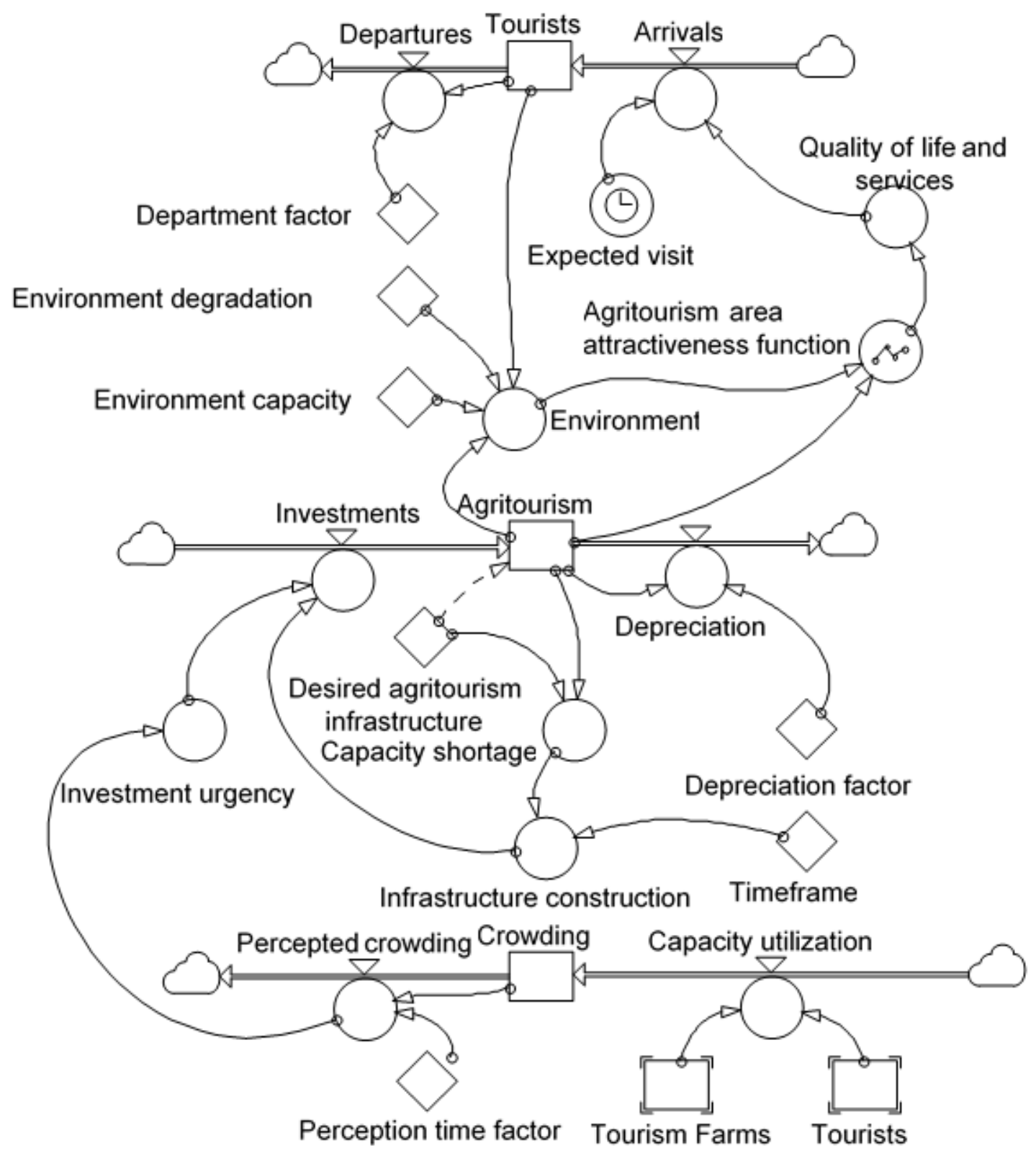

Fig. 3: SD diagram of agritourism simulation model 
As in (Woosnam and Norman, 2010; Woosnam et al. 2009, Wang and Pfister 2008; Harrill 2004)indicated increased traffic in the area influences on local residents as well as the attitudes of residents in general to tourism development (Woosnam and Norman, 2010; Woosnam et al. 2009 Wang and Pfister 2008). System dynamics modelling employs a set of techniques that allow both quantitative and a realistic representation of variables that are typically perceived to be qualitative. Using simulations, companies can test out tactical decisions and experiment with marketing or productdevelopment strategies. The purpose of simulations is to help people understanding the basics of business and in particular the financial implications of various decisions.

\section{EVALUATION OF A DECISION-MAKING MODEL FOR AGRITOURISM}

Agritourism is a type of tourism business system. If we want to evaluate a decision-making model developed for agritourism we must take a business system simulator. Its core is a simulation model. The standard steps of the problem solving method with simulation model are state analysis, development of causal-loop diagrams, writing of the model's equations, and model implementation. The scenarios (which represents the possible future action in the real system), are created by a group of experts determine agritourism market in a certain environment. They are tested on a simulator, which is connected to the GSS (Group Support System) and a database necessity for simulation model activation. The results of simulation are evaluated with GSS and ES (expert systems), which increases the understanding of the system.

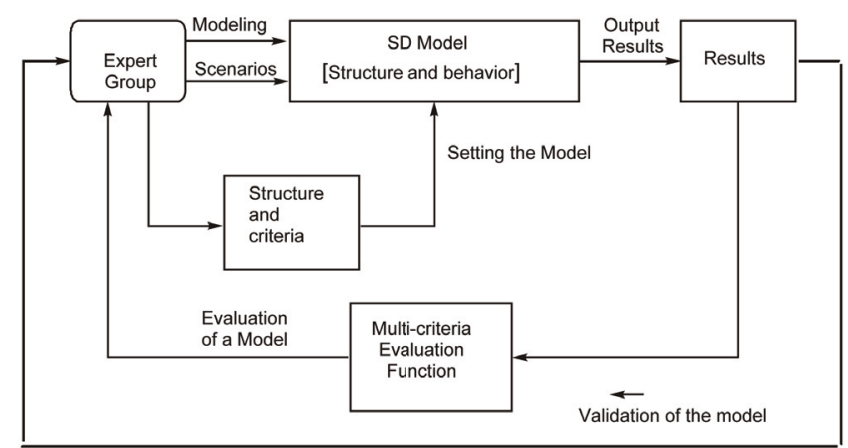

Fig. 4: The scheme of simulation methodology for decisionmaking support

Fig. 4 shows a principle scheme of a simulation system for decision assessment in agritourism. A knowledge capturing process in the form of the structure and behaviour of the model, is represented by scenarios and modelling. Experimentation with different scenarios is possible, when the model is defined and validated. The results gathered as the output of the model are evaluated with the multi-criterial evaluation function. At this stage, many different multicriterial evaluation methods may be used from weighted average (Vincke 1992) to the Analytical Hierarchy Process (AHP), (Saaty 1990) and Expert systems (ES) (Rajkovič and Bohanec 1991) with DEXi software (Bohanec 2016).
Information feedback provides the expert group with

the possibility to creatively determine a new set of scenarios and multi-criterial evaluation functions relating to the given situation (Jere Jakulin 2014). Results are continuously mediated to the expert group, providing an informational feedback loop in the learning process, which has a significant impact on the decision process, as preliminary analysis has indicated. Since work with this tool is anonymous, the participants (group of experts) become relaxed, effective and more creative in modelling and making scenarios. The final result is better as the decision becomes a group decision with which conflict between polarised groups is minimized and a consensus is achieved for the development of further actions. It is important that agritourism decision-making systems fulfil the needs of agritourism suppliers and users of its services: i) Decision-making of agritourism suppliers for their rational and qualitative service in co-operation with a tourist and ii) Enable a tourist the use of the communication system for global decision making and work indifferent problem areas (Kljajić and Jere Lazanski 2005).

\section{CONCLUSION}

Decision-making in agritourism is a complex activity, which requires an excellent approach for optimal results. This paper presented a system of simulating methods, techniques and expert systems as a functional part of decision-making and participation in agritourism. For an illustration of a methodology, we analysed agritourism as a complex system. Environmental, investment (economic) and social factors represent a complex agritourism system. As an attempt to show excellent methodology, we used tools of system dynamics and systems thinking for the decisionmaking processes. Finally, yet importantly we showed with a development of a causal loop diagram of agritourism model and consequently its system dynamics model. The advantages can be claimed for system dynamics modelling over more traditional statistical correlation modelling. We showed that the graphical interface makes apparent the relationships between key variables, and that qualitative data can be readily incorporated into the model. We presented that the model readily integrates with database type pavement management systems, significantly enhancing their potential for scenario analysis.

\section{REFERENCES}

1. Bockermann, A., Meyer, B., Omann, I., Spangenberg, J.H., 2005. Modelling sustainability: comparing an econometric (PANTA RHEI) and a system dynamics model (SuE). Journal of Policy Model. 2005; 27, 189-210.

2. Bohanec M. DEXi HTML evaluator: a software package for running DEXi models in Web browsers. Ljubljana Inst. Jožef Stefan. 2016;

3. Elshorbagy A, et al. System dynamics approach to assess the sustainability of reclamation of disturbed watersheds. Can. J. Civ. Eng. 2005; 32: 144-158 
4. Forrester J. W., System dynamics, systems thinking, and soft OR. Syst. Dyn. Rev. 1994; 10: 245-256.

5. Harrill, R. Residents' Attitudes toward Tourism Development: a Literature Review with Implications for Tourism Planning. Journal of Planning Lit. 2004; 18: 251-266

6. Jere Jakulin T. Systems approach for optimal decisionmaking in event tourism. In: Arsovski S. et al. Conference Manual. Kragujevac: Faculty of Engineering. 2014; 709-715

7. Jere Lazanski, T. System dynamic models to support decision-making in tourism. In Ovsenik R, Kiereta, I. Destination Mgmt.P. Lang 2006; 36-89

8. Kidd J. Hospitality on the Farm: The Development of a Systems Model of Agritourism. ASEAN Journal on Hospitality and Tourism. 2011; 10: 1.

9. Kljajić M, Kljajić Borštnar, M. Context-dependent modelling and anticipation the other coin of the system approach. In Asproth, Viveca, (ed.), Challenges for the future in an ICT context. Sundsvall. Dept of Tech. and Media. Mid Sweden University. 2011; 61-75.

10. Kljajić M, Jere Lazanski, T. Systems Approach to Complex Systems modelling. Acta Syst. 2005; 5: 1-6

11. Kljajić M., Škraba A. Rozman Č. Methodology of system dynamics for decision support in agriculture. Agricultura 2012; 9: Nr.1-2 (Speciall Issue ): 7-16

12. Kljajić M., Contribution to anticipative systems meaning and understanding. In Dubois, Daniel (ed.).Fourth International Conference on Computing Anticipatory Systems, Hec Liège, CHAOS - Centre for Hyperincursion and Anticipation in Ordered Systems: Institute of Mathematics. 2000; 15-16.

13. Senge P. The Fifth Discipline: The Art and Practice of the Learning Organization. Random House Cornerstone Publ; London.UK. 2010.

14. Rajkovič V, Bohanec M. Decision support by knowledge explanation, in environments for supporting decision processes, (Eds. Sol G.H., Vecsenyi J.), North-Holland. 1991; 47-57.

15. Ropret $M$, et al. The systems approach to the improvement of innovation in Slovenian tourism. Kybernetes. 2014; 43: 427-444

16. Rozman Č, et al. The dynamic simulation of organic Farming development scenarios - A case study in Slovenia. Computers and Electronics in Agriculture. Elsevier. 2013; 163-172

17. Saaty T. L. Multicriteria Decision Making; the Analytic Hierarchy Process, RWS Publications, Pittsburgh, USA, 1990.

18. Saysel A.K. et al. Environmental sustainability in an agricultural development project: a system dynamics approach. J. Environ. Manage. 2002; 64: 247-260.

19. Vennix J. A. M. Group model building: facilitating team learning using system dynamic: John Wiley \& Sons Ltd, New Jersey, USA, 1996.

20. Vincke P. Multicriteria Decision-Aid, John Wiley \& Sons Ltd, New Jersey, USA, 1992.

21. Wang Y.A, Pfister, R.E. Residents' Attitudes toward Tourism and Perceived Personal Benefits in a Rural Community. Journal of Travel Research, 2008; 47: 84-93

22. Woosnam K. M, William, C.N.,. Tyanyu Y., Exploring the
Theoretical Framework of Emotional Solidarity between Residents and Tourists. Journal of Travel Res. 2009; 48: 245-258.

23. Woosnam K. M, Norman W.C. Measuring Residents' Emotional Solidarity with Tourists: Scale Development of Durkheim's Theoretical Constructs. Journal of Travel Res. 2010; 49: 365-380.

24. Yunis E. Tourism and employment: An overview by UNWTO. The Fifth UNWTO International Conference on Tourism Statistics: Tourism and Engine for Employment Creation UNWTO, Bali, Indonesia, 2009. 


\section{Modeli sistemske dinamike kot orodja odločanja za turizem na podeželju}

\section{IZVLEČEK}

Turizem na podeželju je kot tržna niša turizma kompleksen in mehko definiran pojav. Medsebojne povezave turističnih kmetij z okoljem, gospodarstvom (investicije, promet) in z družbenimi dejavniki (turisti) zahtevajo hitre in celovite rešitve. Mnogo različnih metodologij in metod obvladuje mehko strukturirana vprašanja in dileme lokalnih in globalnih razsežnosti. V članku predstavljamo metodi sistemskega mišljenja in sistemske dinamike, ki sta bili prvič predstavljeni $\mathrm{v}$ okolju izobraževanja in usposabljanja v obliki raznih računalniških simulacij in kasneje kot orodji za odločanje ter organizacijski re-inženiring. Z namenom predstavitve primernosti metodologije, $\mathrm{v}$ članku razvijemo modele sistemske dinamike. Ti modeli so v bistvu enostavni in služijo kot opisovalci osnovnih medsebojnih vplivov kriterijev. Pozornost posvečamo metodologiji za določanje vrednosti kriterijev modela in tako imenovanemu mentalnemu modelu. Leta predstavlja osnovo vzročnih povezav med kriteriji modela. Na koncu obnovimo povezavo med kvalitativnim in kvantitativnim modelom v okviru sistemske dinamike.

Ključne besede: turizem na podeželju, večkriterijsko odločanje, modeliranje sistemska dinamika 